\title{
Evaluation of Pre-service Teachers' Views Related to Microteaching Practice ${ }^{i}$
}

\author{
Mesut Özonur ${ }^{1, *}$, Halil Kamıșlı \\ ${ }^{1}$ Adana Vocational School of Higher Education, Çukurova University, Turkey \\ ${ }^{2}$ Faculty of Educational Science, Final International University, TRNC
}

Copyright $\odot 2019$ by authors, all rights reserved. Authors agree that this article remains permanently open access under the terms of the Creative Commons Attribution License 4.0 International License

\begin{abstract}
The microteaching method offers opportunities to pre-service teachers for both planning and applying teaching methods-techniques. This method generally focuses on teacher behaviors. In teacher training programs, pre-service teachers learn the theoretical underpinnings of pedagogical strategies, and then they practice these strategies, ensuring them have internalized these skills. Education Faculty needs to be able to review research demonstrating the efficacy of microteaching to feel confident about utilizing this practice in their programs. The aim of this research is to identify pre-service teachers' views related to microteaching practice. This research is a descriptive survey study. The participants include pre-service teachers who study in Computer and Instructional Technology Department in Education Faculty. The Interview Form, the Peer Review Form and Self Evaluation Form were used to collect data in the study. Content analysis method was used for analysis of the data. Within the scope of the research, most of the pre-service teachers reported positive views about micro-teaching. In addition, pre-service teachers' views on peer and self-evaluation were also identified.
\end{abstract}

Keywords Instruction, Micro-teaching, Pre-service Teacher, Teacher Education

\section{Introduction}

The rapid pace of change in the $21^{\text {st }}$ century requires individuals to have the flexibility to adapt to the complexity around them. Learning in this age means adapting to the change. Individuals who attempt to adapt to this process should have the critical $21^{\text {st }}$ century skills to sustain self-development and it is possible only with education to achieve this purpose. The process of education includes many elements such as students, curriculum, schools and instructional tools. Achieving the targeted educational goals depends on organizing these elements in direction with a plan. Among these elements, teacher factor is a crucial element in this process because they play a significant role on acquisition of the behaviors expected from students. It should be put emphasis on training qualified teachers in order to increase the educational quality of nation at a desired level. There are conducted many studies in Turkey and globally related to training qualified teachers, it is also thought that Education Faculties have an important responsibility concerning this issue.

In Education Faculties in Turkey, it is planned within the context of teacher training programs that pre-service teachers are first taught about theoretical knowledge, and then they are expected to put into practice their theoretical knowledge by making observations and teaching practices at schools. During this process, it is aimed that pre-service teachers comprehend effective teaching strategies they'll need in their professional life and have experiences related to teaching process [18].

Not only content knowledge related to their teaching areas, pre-service teachers should also get prepared for their profession by acquiring teaching roles. For purpose of this aim, it is necessary to plan authentic teaching practices in which they can have teaching experiences. Therefore, microteaching practice is used for preparing pre-service teachers for their teaching profession by allowing them opportunities of teaching experiences.

Microteaching was developed as a part an experimental design in 1960 by Dwight W. Allen and his colleagues - a group of educators- for purpose of increasing the quality of teacher training in Stanford University in the USA [1]. It has been applied in Turkey since 1990s [10]. Microteaching is a compacted instruction, which serves the following three aims [1]:

1) Providing a preliminary experience and practice in teaching.

2) As a vehicle for research about the effects of teaching-learning process under controlled circumstances

3) As a vehicle for in-service education for experienced teachers. 
Recently, microteaching is mostly used for preliminary experience and practice in teaching. Microteaching method offers preservice teachers with the opportunities for planning and applying teaching method and techniques. In general, this method focuses on teacher behaviors. Therefore, it aims to help pre-service teachers adopt and acquire these behaviors.

Research suggests that qualified teachers "matter more to student achievement than any other aspect of schooling" [17]; therefore training qualified teaches is essential to achieving national educational goals. Additionally, this fact comes out in findings of Darling-Hammond's study, which reveal that measures of teacher preparation and certification are by far the strongest correlates of student achievement in reading and mathematics [2]. In addition to content knowledge, a qualified teacher is expected to have teacher competences such as planning, communication and direct instruction related to teaching process of a course. It is necessary for pre-service teachers to acquire a variety of teaching skills like guiding discussions and applying classroom management principles as well as learning theoretically what qualities a teacher should have and how to plan a course. However, relevant practices appropriate for acquisition of these skills might be ignored in traditional teacher training programs. This situation may result in teachers who are theoretically knowledgeable in terms of teaching profession but deprived of experience and practice skills $[4,5]$. For solution to this problem, microteaching method is regarded as an effective method for putting theoretical knowledge into practice in acquisition of these skills. In accordance with this aim, in order to train qualified teachers at expected level, it is considered important to conduct studies analyzing the effectiveness of microteaching method in teaching programs. For this reason, problem statement of this research has been created as "What are the pre-service teachers' views about microteaching method?" Within this context, the following questions are attempted to be answered:

1) What are the pre-service teachers' views about microteaching practice?

2) What are the pre-service teachers' views about peer review in microteaching practice?

3) What are the pre-service teachers' views about self-evaluation in microteaching practice?

\section{Materials and Methods}

This research is a descriptive study in survey model which aims to identify the views of pre-service teachers about microteaching practice.

\subsection{Participants}

Participants of this research include pre-service teachers in Computer and Instruction Technologies Department in Education Faculty. This research was conducted during 2015-2016 Spring Term. This application was conducted by researcher. 46 pre-service teachers got involved in practice who took the course of Special Teaching Methods 2 and their ages varied between 20 and $24(41 \%-19$ females, $59 \%$ - 27 males). 3 pre-service teachers who failed to attend the course did not complete the practice.

\subsection{Data Collection Tool}

Interview Form, Peer Review Form and Self Evaluation Form were used for data collection. Interview Form includes questions aimed at identifying positive and negative aspects of microteaching, the difficulties of this method and suggestions related to how to apply this method. Peer Review Form includes 16 items, which were formed after reviewing literature. Similar forms, which were used in studies related to microteaching were analyzed for item composition process. The first tool, Microteaching Form consists of four basic titles which include "Introduction to Course", "Teaching a Lesson and Activities", "Closure of a lesson and Evaluation" and lastly "An Overview Stage. The second tool, Self-Evaluation Form consists of questions, which cover main headings like Professional Contribution, Strengths/ Weaknesses and Practice Again. All data-collection tools were reviewed by experts in Curriculum \& Instruction department and Assessment \&Evaluation department. Revisions were made to ensure the validity of each tool.

\subsection{Application Process}

Microteaching practices in this research were conducted within the scope of a course, namely Special Teaching Methods 2. For microteaching practices, pre-service teachers were asked to choose specific subjects from Information Technologies curriculum; then select and apply strategies, methods and techniques appropriate for this subject. Microteaching practices were actualized in the following stages:

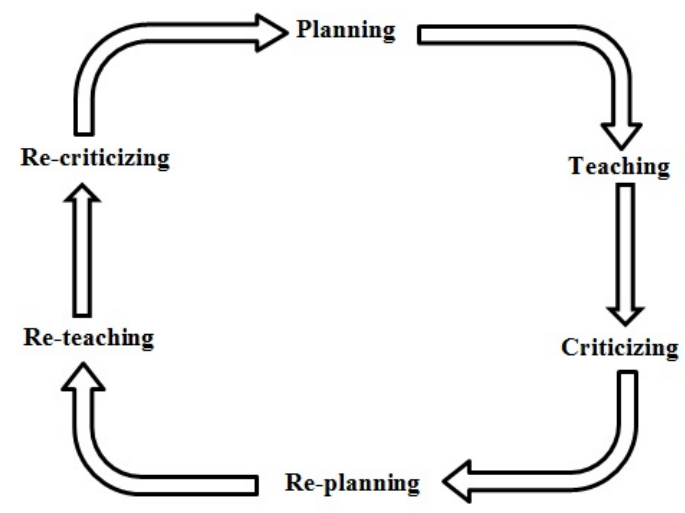

Figure 1. Microteaching stages [15] 
Higgins and Nicholl [7] in their studies state that microteaching is a cycle. In this study, using these cycle stages above as a basis, the following acts were done:

1) Pre-service teachers were asked to make a lesson plan for their first microteaching practice.

2) They were asked to make their first presentation and create a video record.

3) Instructor Evaluation and Peer Reviews were obtained related to first practice.

4) They were asked to make the lesson again in accordance with suggestions.

5) They were again asked to make their presentations and create a video record.

6) Instructor Evaluation and Peer Reviews were obtained related to second practice. In all evaluations, pre-service teachers' mistakes or their missing aspects were corrected [8].

Also, pre-service teachers were asked to make a self-evaluation after two microteaching practices in which they focused on each other's practice and their own strengths/weakness in microteaching practice. Lastly, all pre-service teachers' views about microteaching practice were gathered via Interview Form at the end of semester.

\subsection{Data Analysis}

Data were obtained with Interview Form, Peer Review Form and Self-Evaluation Form. Content analysis method was used for analyzing the data obtained from Interview Form and Self-Evaluation Form. Frequency analysis was done for analyzing the data obtained from Peer Review Form.

Among qualitative data analysis methods, content analysis was used for analyzing the data obtained from open-ended questions. Content analysis reveal the concepts emerging from coding process and the relationship between these concepts [20].

The data obtained from open-ended questions were separately analyzed and coded by both researcher and an expert. The reliability of qualitative data was found out by using two raters' agreement percentage (inter-rater reliability) formula suggested by Miles and Huberman [19]. Agreement percentage in analysis of open-ended questions was given in the following lines:

Agreement percentage related to pre-service teachers' views about positive aspects of microteaching was found to be 0,88 .

Agreement percentage related to pre-service teachers' views about negative aspects of microteaching was found to be 1,00 .

Agreement percentage related to challenges in application of microteaching method was found to be 1,00 .

Agreement percentage related to suggestions in application of microteaching method was found to be 1,00 .

Agreement percentage related to contribution of microteaching method to professional development was found to be 0,90 .

Agreement percentage related to question "What are your strengths and weaknesses during application?" was found to be 0,90 for first practice and 0,92 for second practice.

Agreement percentage related to question "What kind of revisions would you make if you did the same practice again?" was found to be 0,92 .

\section{Results}

This section includes findings obtained from data collection tools developed within context of this research. These findings are presented in the following tables according to each subproblem.

The findings related to pre-service teachers' views about microteaching method are given in Table 1, Table 2, Table 3 and Table 4.

Table 1. Descriptive Statistics about positive aspects of microteaching

\begin{tabular}{|l|l|}
\hline Positive Aspects & f \\
\hline Providing Experience of Lesson Preparation and Planning & 33 \\
\hline Self-Development in Terms of Teaching Methods & 28 \\
\hline Developing Presentation Skills & 25 \\
\hline Classroom Management Experience & 23 \\
\hline Controlling Excitement and Stress & 22 \\
\hline Teaching the Skill of How to Communicate with Students & 15 \\
\hline Teaching How to Make a Proper Introduction in a Lesson & 9 \\
\hline
\end{tabular}

Table 1 presents pre-service teachers' answers related to positive aspects of microteaching. The most frequent views expressed by pre-service teachers include providing experience of lesson preparation and planning, self-development in terms of teaching methods, acquiring presentation skills, classroom management experience, controlling excitement and stress, teaching the skill of how to communicate with students, teaching how to make a proper introduction to a lesson. Table 2 presents findings related to negative aspects of microteaching method.

Table 2. Descriptive statistics about negative aspects of microteaching

\begin{tabular}{|l|l|}
\hline Negative Aspects & f \\
\hline Experiencing Fear of Making Mistake & 15 \\
\hline Experiencing Fear of Being Criticized & 12 \\
\hline Teaching a Lesson not in Real Setting & 6 \\
\hline Insufficient Duration & 5 \\
\hline
\end{tabular}

As seen in Table 2, among negative aspects of microteaching, pre-service teachers express that they mostly experience fear of making mistake and being criticized. Table 3 presents findings related to challenges in application of microteaching method. 
Table 3. Descriptive statistics about challenges in application of microteaching method

\begin{tabular}{|l|l|}
\hline Challenges & f \\
\hline Experiencing Stress & 14 \\
\hline Time Management & 11 \\
\hline Insufficient Content Knowledge & 8 \\
\hline Inability to decide a method-technique & 6 \\
\hline Making Speech in front of a Group & 3 \\
\hline
\end{tabular}

As seen in Table 3, the most frequently expressed challenges during application of microteaching are experiencing stress and time management. Table 4 presents findings related to suggestions in application of microteaching.
As seen in Table 4, the most frequently expressed suggestions by pre-service teachers include using this method in other courses, applying in real class setting and inclusion of different students instead of classmates.

Table 4. Descriptive statistics related to suggestions in application of microteaching method

\begin{tabular}{|l|l|}
\hline Suggestions & f \\
\hline Using this method in other courses, too & 13 \\
\hline Applying in real class setting & 11 \\
\hline Including different students instead of classmates & 9 \\
\hline
\end{tabular}

Table 5 presents the findings about pre-service teachers' views related to Peer Review in Microteaching.

Table 5. Descriptive statistics related to peer review in microteaching practice

\begin{tabular}{|c|c|c|c|c|c|c|c|c|c|c|}
\hline & \multicolumn{5}{|c|}{ 1.Practice } & \multicolumn{5}{|c|}{ 2.Practice } \\
\hline $\begin{array}{c}\text { Stage 1: Introduction } \\
\text { to a Lesson }\end{array}$ & $\begin{array}{l}\text { Very } \\
\text { good }\end{array}$ & Good & Moderate & Insufficient & $\begin{array}{c}\text { Not } \\
\text { exist }\end{array}$ & $\begin{array}{l}\text { Very } \\
\text { good }\end{array}$ & Good & Moderate & Insufficient & $\begin{array}{l}\text { Not } \\
\text { exist }\end{array}$ \\
\hline $\begin{array}{c}\text { Giving learning } \\
\text { outcomes }\end{array}$ & 93 & 311 & 442 & 88 & 15 & 208 & 479 & 202 & 52 & 6 \\
\hline $\begin{array}{c}\text { Enabling students' } \\
\text { motivations }\end{array}$ & 101 & 302 & 481 & 55 & 8 & 199 & 490 & 219 & 38 & 3 \\
\hline $\begin{array}{c}\text { Prompting students' } \\
\text { prior knowledge }\end{array}$ & 109 & 320 & 456 & 52 & 8 & 165 & 440 & 302 & 36 & 2 \\
\hline \multicolumn{11}{|l|}{$\begin{array}{l}\text { Stage 2: Teaching a } \\
\text { Lesson and Activities }\end{array}$} \\
\hline $\begin{array}{l}\text { Appropriateness of } \\
\text { content }\end{array}$ & 113 & 295 & 486 & 47 & 6 & 253 & 497 & 175 & 22 & 0 \\
\hline $\begin{array}{l}\text { Appropriateness of } \\
\text { teaching } \\
\text { methods/techniques }\end{array}$ & 63 & 328 & 491 & 56 & 9 & 173 & 512 & 232 & 27 & 1 \\
\hline $\begin{array}{l}\text { Appropriateness of } \\
\text { teaching materials }\end{array}$ & 98 & 316 & 487 & 39 & 5 & 212 & 505 & 218 & 12 & 0 \\
\hline $\begin{array}{l}\text { Appropriateness of } \\
\text { examples given to } \\
\text { students in terms of their } \\
\text { level }\end{array}$ & 87 & 312 & 491 & 44 & 11 & 217 & 498 & 219 & 13 & 0 \\
\hline $\begin{array}{l}\text { Providing students' } \\
\text { participation in lesson }\end{array}$ & 107 & 278 & 492 & 58 & 13 & 241 & 515 & 169 & 24 & 0 \\
\hline $\begin{array}{c}\text { Giving appropriate and } \\
\text { clear feedback to } \\
\text { students }\end{array}$ & 100 & 308 & 481 & 45 & 11 & 219 & 499 & 210 & 19 & 1 \\
\hline \multicolumn{11}{|l|}{$\begin{array}{l}\text { Stage 3: Closure of a } \\
\text { Lesson and Evaluation }\end{array}$} \\
\hline $\begin{array}{l}\text { Appropriateness of } \\
\text { evaluation strategies }\end{array}$ & 140 & 209 & 512 & 71 & 14 & 274 & 299 & 345 & 25 & 2 \\
\hline $\begin{array}{c}\text { Making summary of } \\
\text { lesson }\end{array}$ & 121 & 306 & 448 & 57 & 13 & 234 & 458 & 226 & 26 & 3 \\
\hline $\begin{array}{l}\text { Making associations } \\
\text { with the next lesson }\end{array}$ & 193 & 283 & 411 & 49 & 9 & 402 & 424 & 109 & 13 & 0 \\
\hline \multicolumn{11}{|l|}{$\begin{array}{c}\text { Stage 4: A General } \\
\text { Overview }\end{array}$} \\
\hline Using time & 127 & 342 & 416 & 51 & 11 & 251 & 527 & 152 & 17 & 0 \\
\hline $\begin{array}{c}\text { Making associations } \\
\text { between subject and real } \\
\text { life }\end{array}$ & 98 & 307 & 451 & 84 & 8 & 209 & 507 & 195 & 32 & 2 \\
\hline $\begin{array}{l}\text { Attitudes towards } \\
\text { students }\end{array}$ & 104 & 298 & 467 & 73 & 5 & 218 & 500 & 217 & 11 & 1 \\
\hline $\begin{array}{l}\text { Establishing effective } \\
\text { communication with } \\
\text { students }\end{array}$ & 131 & 311 & 436 & 62 & 7 & 213 & 511 & 202 & 20 & 1 \\
\hline
\end{tabular}


As seen in Table 5, pre-service teachers' views related to peer review in microteaching have been analyzed according to the following categories: introduction of a lesson, teaching lesson and activities, closure of a lesson and evaluation, a general overview. Especially after second microteaching practice, it is found out that pre-service teachers think their mates are mostly at a good level.

Table 6, Table 7, Table 8 and Table 9 present the findings about self-evaluations of pre-service teachers related to microteaching practice. Table 6 shows the findings about pre-service teachers' views whether their own microteaching practices contribute to their professional development.

Table 6. Descriptive statistics about the question of "do your own microteaching practices contribute to your professional development?"

\begin{tabular}{|c|c|}
\hline & f \\
\hline Yes & 42 \\
\hline No & 1 \\
\hline
\end{tabular}

As seen in Table 6, most of the pre-service teachers replied yes to the question of "Do your own microteaching practices contribute to your professional development?" Table 7 presents the findings about microteaching practices' contribution to professional development.

As seen in Table 7, pre-service teachers focus on microteaching's contribution to professional development mostly in terms of having experience of teaching practice, gaining skill of speaking in front of a group, increasing self-confidence, experience of planning a lesson, experience of applying different methods-techniques, experience of preparing course material, developing skill of controlling anxiety, realizing the missing issues during process and developing gesture-mimic, intonation skills.

Table 7. Descriptive statistics about microteaching practices' contribution to professional development

\begin{tabular}{|l|l|}
\hline Contributions & f \\
\hline Having Experience of Teaching Practice & 40 \\
\hline Gaining skill of speaking in front of a group & 38 \\
\hline Increasing self-confidence & 34 \\
\hline Experience of planning a lesson & 33 \\
\hline Experience of applying different methods-techniques & 29 \\
\hline Experience of preparing course material & 28 \\
\hline Developing Skill of Controlling Anxiety & 28 \\
\hline Realizing the missing issues during process & 20 \\
\hline Developing Gesture-mimic, intonation skills & 14 \\
\hline
\end{tabular}

Table 8 presents pre-service teachers' strengths and weaknesses during first and second microteaching practice.

As seen in Table 8, pre-service teachers list their strengths during first microteaching as presentation skill, classroom management, communication with students, providing students' participation in lesson, giving right examples appropriate for subject, time management and conducting all planned activities. However, they also lists their weakness as inability to control anxiety, classroom management, self-confidence problem, time management, presentation skills, communication with students, conducting only a part of planned activities, giving examples appropriate for subject. Additionally, as seen in Table 8, pre-service teachers list their strengths during second microteaching as presentation skill, classroom management, communication with students, providing students' participation in lesson, giving right examples appropriate for subject and time management; however, they list their weakness during second practice as inability to control anxiety, not having adequate knowledge of subject and self-confidence problem. When data are examined in detail, there is observed a positive increase after second microteaching practice in findings related to strengths and weaknesses. Table 9 presents the findings, which reveal what kind of improvements would they make if they did the same practice again?

Table 8. Descriptive statistics related to the question of "what are your strengths and weaknesses during microteaching practices?"(1st evaluation)

\begin{tabular}{|c|c|c|}
\hline Strengths & $\begin{array}{l}\text { f (1st } \\
\text { Practice) }\end{array}$ & $\begin{array}{l}\text { f (2nd } \\
\text { Practice) }\end{array}$ \\
\hline Presentation skill & 27 & 35 \\
\hline Classroom management & 26 & 33 \\
\hline Communication with students & 21 & 29 \\
\hline $\begin{array}{l}\text { Providing students' } \\
\text { participation in lesson }\end{array}$ & 19 & 27 \\
\hline $\begin{array}{l}\text { Giving right examples } \\
\text { appropriate for subject }\end{array}$ & 16 & 25 \\
\hline Time management & 16 & 22 \\
\hline $\begin{array}{l}\text { Conducting all planned } \\
\text { activities }\end{array}$ & 15 & 20 \\
\hline $\begin{array}{l}\text { Making associations between } \\
\text { subject and daily life }\end{array}$ & 8 & 13 \\
\hline Presenting course materials & 3 & 8 \\
\hline \multicolumn{3}{|l|}{ Weaknesses } \\
\hline Inability to control anxiety & 33 & 15 \\
\hline Classroom management & 32 & 6 \\
\hline Self-confidence problem & 29 & 10 \\
\hline Time management & 27 & 2 \\
\hline Presentation skills & 25 & 7 \\
\hline Communication with students & 23 & 5 \\
\hline $\begin{array}{l}\text { Conducting only a part of } \\
\text { planned activities }\end{array}$ & 19 & 6 \\
\hline $\begin{array}{l}\text { Giving examples appropriate } \\
\text { for subject }\end{array}$ & 15 & 2 \\
\hline Mastery of Subject & 12 & 12 \\
\hline Intonation & 11 & 2 \\
\hline Using language in a good way & 9 & 3 \\
\hline Not taking serious of subject & 3 & 1 \\
\hline
\end{tabular}

As seen in Table 9, pre-service teachers expressed what revisions they would make if they had a chance to do the 
same practice again in microteaching and their expressions include choosing a better method-technique for the subject, planning lesson more carefully, planning activities ensuring students' participation, a more effective instruction, teaching according to students' level.

Table 9. Descriptive statistics related to the question of "what kind of revisions would you make if you did the same practice again?"

\begin{tabular}{|l|l|}
\hline Revisions & f \\
\hline Choosing a better method-technique for the subject & 22 \\
\hline Planning lesson more carefully & 18 \\
\hline Planning activities ensuring students' participation & 17 \\
\hline A more effective instruction & 15 \\
\hline Teaching according to students' level & 14 \\
\hline Making changes in course material & 11 \\
\hline Making associations with the next lesson & 10 \\
\hline Using time more effectively & 9 \\
\hline Changes in content & 7 \\
\hline Making a better introduction to lesson & 3 \\
\hline Reducing the number of students & 2 \\
\hline Attempting to gamify the course & 1 \\
\hline
\end{tabular}

\section{Discussion}

This study aims to identify the pre-service teachers' views related to microteaching practice within the context of Special Teaching Methods 2 Course. The views of pre-service teachers related to microteaching practice have been obtained under the following categories: general evaluation, peer review and self-evaluation.

It is concluded that microteaching practices contribute to development of pre-service teachers in a positive way in terms of providing experience of lesson preparation and planning, self-development in terms of teaching methods, developing presentation skills, classroom management skill, controlling stress and anxiety. In addition to content knowledge, a qualified teacher is expected to have teacher competences such as planning, communication and instruction related to teaching process of a course. Pre-service teachers who get education theoretically about teaching profession need to go through experience, which allows to apply their knowledge. At this point, microteaching practices offer opportunities for going through this experience. In this way, pre-service teachers get experience related to teaching profession at the end of practice.

Within the context of this study, pre-service teachers who participated in microteaching practices have recognized and expressed the contributions of these practice to their professional development. The findings about microteaching's positive contributions in this study are in parallel with the results of other studies $[3,12,13,14$, $16]$.
Pre-service teachers express that they might experience fear of making mistake, being criticized, stress and time management problems during microteaching practices, just like in study of Mergler \& Tangen [13]. In self-evaluation process, pre-service teachers make some evaluations as inability to control anxiety, insufficient content knowledge and self-confidence problem. The aim of microteaching practices is to help pre-service teachers acquire desired competences by allowing them teaching experiences. It is an expected result that pre-service teachers might have these challenges when they first experience this. The similar findings were obtained in other studies, too [11].

Microteaching practices have contributed to professional developments of pre-service teachers in terms of teaching profession experience, developing the skill of speaking in front of a group, increasing self-confidence, lesson planning, using different methods-techniques, course material development experience and developing the skill of controlling anxiety. Microteaching practices whose focus is to provide pre-service teachers with preliminary experience during teacher training programs served its aims in this research and made contributions to pre-service teachers' professional development. The essential point of this research relies on positive contributions of microteaching practices in teacher training. The findings of some other research support this finding, too $[6,9,14,16]$.

Within context of this research, pre-service teachers made self-evaluation and peer reviews related to microteaching practices. One of the objectives of this activity is to help pre-service teachers recognize strengths, weaknesses or missing issues related to teacher practice skills and make necessary improvements and suggestions. In this research, they have identified their strengths and weaknesses by making evaluations of their own practices and their peers' practices, just like in studies of Fernandez [3] and McCullagh \& Murphy [12]. Meanwhile, they have expressed that if they did this practice again, they would do improvements in areas of choosing a better method-technique appropriate for the subject, planning the course more carefully, planning activities increasing students' participation, making a more effective instruction. These improvements are in parallel with findings related to pre-service teachers' weaknesses in microteaching practice. Also, after first and second microteaching, when pre-service teachers' self-evaluations and peer reviews are examined in detail, there is observed an increase in their evaluations in a positive way. This result indicates that pre-service teachers have noticed their shortcomings during microteaching practices and attempted to find ways for these shortcomings. This makes a match of microteaching practice's objective. Therefore, it is possible to claim that microteaching practice within the context of this research achieved its aims and became a successful application. This result is also supported by He \& Yan's [6] study. 


\section{Conclusions}

- Within the context of this research, it is found out that pre-service teachers think that microteaching practice include positive aspects such as providing experience of lesson preparation and planning, self-development in terms of teaching methods, acquiring presentation skills, classroom management experience, controlling excitement and stress.

- However, it is also found out that pre-service teachers think that microteaching practice include negative aspects such as fear of making mistakes and being criticized.

- During microteaching practices, pre-service teachers experience challenges such as stress and time management

- Related to microteaching, pre-service teachers make suggestions such as using it in other courses, applying in real class setting and using with different students instead their mates.

- Within the context of peer reviews aimed at microteaching practices, especially after second practice, pre-service teachers find their mates mostly good enough in terms of introduction to lesson, teaching a lesson and activities, closure of a lesson and evaluation, a general overview.

- It is found out that pre-service teachers express microteaching practices made contributions to their professional development in terms of having experience of teaching practice, developing skill of speaking in front of a group, increasing self-confidence, planning a lesson, applying different methods-techniques and gaining experience of preparing course material and developing skill of controlling anxiety.

- During first microteaching practice, it is revealed that the strengths of pre-service teachers include presentation skill, classroom management, communication with students, providing students' participation, giving right examples appropriate for subject and time management. Similar findings have been obtained during second microteaching practice, and it also shows a positive increase in results.

- It is found out that pre-service teachers think that microteaching practice include negative aspects such as inability to control anxiety, class management, self-confidence problem, presentation skill and communication with students. Similar findings have been obtained during second microteaching practice, and also it is observed there is a tendency of a decrease.

- If pre-service teachers are required to do microteaching again, they point out the necessity of some changes by making suggestions such as choosing a better method-technique appropriate for subject, planning lesson more carefully, planning activities increasing students' participation, making a more effective instruction, teaching according to students' level.

\section{Suggestions}

- During microteaching practices, practicing in front of their classmates creates more stress for pre-service teachers and their close relationship results in a decrease in listeners' and researcher's motivation. For solution to these problems, microteaching practice can be used in other classrooms.

- Microteaching practices are usually done in Special Education Methods course. In order to allow pre-service teachers more time for practice, this course should be planned again in a weekly schedule.

- Activities related to microteaching should be given more emphasis in teacher training education program.

\section{REFERENCES}

[1] Allen, D. W. (1967). Micro-Teaching: Description. Stanford Teacher Education Program.

[2] Darling-Hammond, L. (2000). Teacher quality and student achievement. Education policy analysis archives, 8(1), $1-44$.

[3] Fernandez, M. L. (2005). Learning through microteaching lesson study in teacher preparation. Action in Teacher Education, 26(4), 37-47.

[4] Frye, H. (1988). The principal's role in teacher preparation. Journal of Teacher Education, 39(6), 54-58.

[5] Goodman, J. (1986). University education courses and the professional preparation of teachers. Teaching and Teacher Education, 12(2).

[6] He, C., \& Yan, C. (2011). Exploring authenticity of microteaching in pre-service teacher education programmes. Teaching Education, 22(3), 291-302.

[7] Higgins, A., \& Nicholl, H. (2003). The experiences of lecturers and students in the use of microteaching as a teaching strategy. Nurse Education in Practice, 220-227.

[8] Kpanja, E. (2001). A study of the effects of video tape recording in microteaching training. British Journal of Educational Technology, 32(4), 483-486.

[9] Kupper, J. B. (2001). The microteaching experience: Student perspectives. Education, 121(4), 830-832.

[10] Külahçı，Ş. (1994). Mikro öğretimde Fırat Üniversitesi Teknik Eğitim Fakültesi deneyimi II.Değerlendirme. Eğitim ve Bilim, 36-44.

[11] Mahmud, I., \& Rawshon, S. (2013). Micro teaching to improve teaching method: An analysis on students' perspectives. IOSR Journal of Research \& Method in Education (IOSR-JRME), 1(4), 69-76. 
[12] McCullagh, J., \& Murphy, C. (2015). From microteaching to microlearning. Belfast; Dublin: Stranmillis University; Trinity College.

[13] Mergler, A., \& Tangen, D. (2010). Using microteaching to enhance teacher efficacy in pre-service teachers. Teaching Education, 21(2), 199-210.

[14] Otsupius, I. A. (2014). Micro-teaching: A technique for effective teaching. An International Multidisciplinary Journal, 8(4), 183-197.

[15] Peker, M. (2009). Genişletilmiş mikro öğretim yaşantıları hakkında matematik öğretmeni adaylarının görüşleri. Türk Eğitim Bilimleri Dergisi, 7(2), 353-376.

[16] Ralph, E. G. (2014). The effectiveness of microteaching: Five years' findings. International Journal of Humanities Social Sciences and Education (IJHSSE), 1(7), 17-28.

[17] RAND Corporation. (2012). Teachers matter: Understanding teachers' impact on student achievement. Santa Monica, CA: Author. Retrieved from https://www.rand.org/pubs/corporate_pubs/CP693z1-2012 $-09 . h t m l$

[18] Turkish National Ministry of Education (2017). Teacher Strategy Report 2017-2023.

[19] Yanpar, T. (2003). Student teachers' perceptions of instructional technology: Developing materials based on a constructivist approach. British Journal of Educational Technology, 34(1), 67-74.

[20] Yıldırım, A., \& Şimşek, H. (1999). Sosyal bilimlerde nitel araştırma yöntemleri. Ankara: Seçkin Yayınevi.

\footnotetext{
${ }^{\mathrm{i}}$ This paper is presented in International Conference on Environmental Sciences \& Educational Studies (ICES 2017)
} 